\title{
A Relativização da coisa julgada: Um conflito entre a Segurança Jurídica e a Justiça da Decisão
}

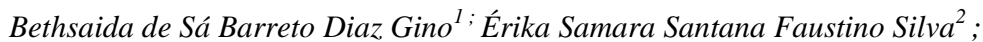 \\ Társis da Costa Carneiro Pontes Dantas ${ }^{3}$
}

\begin{abstract}
Resumo: A coisa julgada ao estabilizar decisões judiciais pondo fim a conflitos de interesses torna-se essencial ao Estado Constitucional Democrático, pois confere paz a coletividade. Esse instituto tem sido alvo de grande polêmica doutrinária acerca da possibilidade ou não da sua relativização de forma atípica, ou seja, fora das hipóteses previstas em lei. As discussões giram em torno do conflito entre dois princípios constitucionais, a saber, a segurança jurídica e o acesso à ordem jurídica justa. Quem defende a possibilidade de relativização da coisa julgada baseia-se no princípio do acesso à ordem jurídica justa, pois tendo o Poder Judiciário a missão de pacificar lides, não se pode admitir sentenças inconstitucionais, injustas ou totalmente desarrazoadas da realidade. Podendo, portanto, tal decisão, ser desconstituída, por qualquer meio e em qualquer tempo. Já os que defendem a impossibilidade de relativização utilizam como argumento, a segurança jurídica, valor supremo que confere imutabilidade a uma decisão impedindo a perpetuação de conflitos. O princípio da proporcionalidade nos apresenta a melhor solução, pois diante de um caso concreto, utilizando a técnica da ponderação, analisa-se qual princípio deve ser utilizado de forma mais abrangente e qual deve ser restringido, solucionando, assim, da melhor forma possível, a questão.
\end{abstract}

Palavras-Chave: Coisa Julgada. Relativização. Ponderação.

\section{The Relativization of res judicata: A conflict between the Legal Security and Justice Decision}

\begin{abstract}
The res judicata by stabilizing court decisions putting an end to conflicts of interest becomes essential to the democratic constitutional state, it gives peace to the community. This institute has been target of a great doctrinaire controversy about the possibility or not of its atypically relativization, that is, outside the cases provided by law. Discussions revolve around the conflict between two constitutional principles, namely the legal certainty and access to fair legal system. Who defends the possibility of relativization of res judicata is based on the principle of access to fair legal system, as the judiciary has the task of pacifying conflicts, can not admit unconstitutional sentences, unfair or completely unreasonable of reality.Therefore, this decision may be dismantled by any means and at any time. But those who argue the impossibility of relativization use as an argument, the legal certainty, supreme value that gives immutability to a decision preventing the perpetuation of conflicts.The principle of proportionality gives us the best solution, because for a concrete case, using the weighting technique, it is analyzed what principle should be used in a more widely way and which one should be restricted, resolving thus in the best way possible the issue.
\end{abstract}

Keywords: res judicata. Relativization. Weighting.

\footnotetext{
${ }^{1}$ Advogada pela Universidade Regional do Cariri - URCA, Pós-graduada em Direito Previdenciário e Trabalhista pela Universidade Regional do Cariri - URCA, Pós-graduada em Direito Processual Civil pela Universidade Regional do Cariri - URCA, Advogada, Sócia Proprietária do Escritório: Dantas \& Gino Advocacia, Primeira Vice-Presidente da Comissão de Direito Imobiliário da Ordem dos advogados do Brasil, Subseccional Juazeiro do Norte, Ceará. E-mail: bethsaidagino@hotmail.com;

${ }^{2}$ Advogada pela Universidade Regional do Cariri (2011) e especialista em Direito Processual Civil. Atualmente é advogada na área cível e Técnica do Seguro Social do Instituto Nacional do Seguro Social. Encontra-se em processo de especialização em Direito Constitucional. Tem experiência na área de Direito, com ênfase em Direito Previdenciário.

${ }^{3}$ Advogado. pela Faculdade Paraíso do Ceará - FAP, Pós-graduando em Direito Trabalho e Previdenciário pela Faculdade Paraíso do Ceará FAP, Advogado, Sócio do Escritório de Advocacia: Dantas, Gino \& Advogados Associados
} 
Id on Line Revista Multidisciplinar e de Psicoloqia

Id on Line Revista Multidisciplinar e de Psicologia

\section{Introdução}

A coisa julgada, que é a imutabilidade das decisões judiciais, foi tratada durante a história como valor absoluto, intocável, pois existia a necessidade de estabilização das sentenças judiciais conferindo às partes a certeza quanto ao seu direito.

Com a evolução da ciência do direito, surgiu um novo paradigma jurídico-social onde não existem direitos absolutos, pois todos encontram limites em outros valores e interesses coletivos previstos na Constituição. Assim, todos os direitos e liberdades devem ser considerados relativos, pois se um não pode ceder, não haverá como resolver um problema em caso de colisão.

Desta forma, surgiu na doutrina brasileira um movimento que pretende a relativização da coisa julgada fora das hipóteses já previstas em lei para sua desconstituição. Com base no princípio do acesso à ordem jurídica justa, afirmam esses autores que uma sentença ou acórdão maculado pela inconstitucionalidade ou injustiça não pode prevalecer no sistema jurídico devendo essa decisão ser revista a qualquer tempo e por qualquer meio.

Acontece que essa nova forma de pensar quanto à desconstituição da coisa julgada encontra resistência de outros vários doutrinadores brasileiros, para os quais a segurança jurídica seria valor supremo, absoluto, que confere estabilidade às relações sociais. Não admitindo, assim, que a coisa julgada seja relativizada por meios outros que não os previstos em lei.

Em virtude desta acesa polêmica doutrinária acerca do instituto da coisa julgada torna-se imprescindível o estudo deste tema, pois há a necessidade de se evidenciar qual princípio deve prevalecer diante de uma situação de conflito em um caso concreto. Se a segurança jurídica for tida como intocável, corremos o risco de perenizar injustiças gerando uma consequente insatisfação social. Se de outro lado o acesso à ordem jurídica justa for utilizado para, em qualquer caso, relativizar a coisa julgada, haverá a insegurança jurídica gerando o descrédito do Poder Judiciário perante a população.

Assim sendo, o conflito entre esses dois princípios constitucionais, a segurança jurídica e o acesso à ordem jurídica justa, deve ser solucionado através do princípio da proporcionalidade (ponderação), onde dependendo da análise do caso concreto, um princípio será aplicado em maior abrangência em detrimento do outro que não deverá ser totalmente excluído, pois também é muito importante para o nosso sistema jurídico.

\section{Objetivos e Metodologia}

A presente pesquisa teve por objetivo geral estudar o fenômeno da coisa julgada e a polêmica quanto à possibilidade de relativização por outros meios que não os já admitidos em nosso 
Id on Line Revista Multidisciplinar e de Psicoloqia

Id on Line Revista Multidisciplinar e de Psicologia

ordenamento jurídico. E, como objetivos específicos, analisar as principais correntes doutrinárias favoráveis e contrárias à relativização, sopesar os princípios constitucionais que estão em conflito e embasam a questão, demonstrar a possibilidade de relativização da coisa julgada por meio do princípio da proporcionalidade (ponderação), sempre que o aplicador do direito vislumbrar em um caso concreto uma decisão extremamente injusta, inconstitucional ou totalmente desarrazoada da realidade e fazer uma breve análise de algumas mudanças ocorridas no instituto da coisa julgada com a entrada em vigor do novo Código de Processo Civil.

A pesquisa desenvolveu-se através do método dedutivo de abordagem, utilizando-se da técnica de pesquisa bibliográfica e da exegese jurídica, tendo como principais fontes, livros doutrinários, artigos científicos, jurisprudências e a legislação aplicável ao caso concreto.

\title{
Noções gerais sobre coisa julgada
}

A coisa julgada ou res judicata é o mecanismo criado pelo ordenamento jurídico objetivando a imutabilidade das decisões judiciais, ou seja, é quando não pode mais ser interposto nenhum recurso, seja porque já passou o lapso temporal para tanto, ou porque já foram esgotadas todas as vias, diz-se então que a decisão transitou em julgado fazendo coisa julgada. O comando normativo contido na decisão torna-se indiscutível dentro e fora do processo. Os efeitos da decisão são agora imodificáveis.

Esse instituto na nossa legislação está alçado à garantia de direito fundamental protegido pelo manto das cláusulas pétreas, pois se encontra previsto no artigo $5^{\circ}$, inciso XXXVI da Constituição Federal de 1988, in verbis: "a lei não prejudicará o direito adquirido, o ato jurídico perfeito e a coisa julgada".

Plácido e Silva (1997 apud FARIA; THEODORO JUNIOR; NASCIMENTO, 2011, p. 34) assim entende:

\begin{abstract}
A coisa julgada pressupõe o julgamento irretratável de uma relação jurídica anteriormente controvertida. Nesta razão, a autoridade res judicata não admite, desde que já foi reconhecida a verdade, a justiça e a certeza a respeito da controvérsia, em virtude da sentença dada, que venha a mesma questão a ser ventilada, tentando destruir a soberania da sentença, proferida anteriormente e considerada irretratável, por ter passado em julgado.
\end{abstract}

Segundo a doutrina brasileira a coisa julgada se divide em formal e material. A formal é a impossibilidade de se discutir a sentença devido à preclusão dos recursos. Assim, depois de prolatada a sentença, esgotados os prazos dos recursos cabíveis, forma-se a coisa julgada formal e o órgão julgador não poderá mais modificar sua decisão, a sentença torna-se irrecorrível. Produz efeitos 
Id on Line Revista Multidisciplinar e de Psicoloqia

Id on Line Revista Multidisciplinar e de Psicologia

endoprocessuais, ou seja, não se pode modificar a decisão final dentro do mesmo processo, mas nada impede que a parte venha a discutir o mesmo tema em outra relação processual.

Ocorre a coisa julgada material (coisa julgada propriamente dita) quando a sentença ou acórdão não podem mais ser discutidos no mesmo processo em que foram prolatados nem em outro processo posterior, tornando a decisão indiscutível. Esse tipo de coisa julgada surge quando o juiz decide o mérito da causa, a disputa existente entre as partes, tendo sido interpostos todos os recursos cabíveis torna-se então imutável a sentença ou acórdão. A coisa julgada material é importante em virtude da segurança jurídica e para que um mesmo fato não seja discutido eternamente. É em face da coisa julgada material que surge a polêmica quanto à possibilidade ou não da sua relativização de forma atípica.

O conceito de coisa julgada estava previsto no CPC de 1973 no artigo 467 que prelecionava: "Denomina-se coisa julgada material a eficácia, que torna imutável e indiscutível a sentença, não mais sujeita a recurso ordinário ou extraordinário.” No novo CPC o conceito migrou para o artigo 502 que dispõe: "Denomina-se coisa julgada material a autoridade que torna imutável e indiscutível a decisão de mérito não mais sujeita a recurso."

Da leitura desses dois dispositivos percebemos clara evolução conceitual, pois ao falar que a coisa julgada era a eficácia da sentença, o CPC de 1973 aparentava dizer que era a coisa julgada que tornava a sentença eficaz, o que não é verdade, pois existem sentenças que embora não transitam em julgado podem ser eficazes, por exemplo, a execução provisória de sentença. Portanto, uma sentença ainda que não transitada em julgado, pode ser executada, sendo eficaz. Fez bem o novo CPC ao substituir a expressão eficácia pela autoridade, tendo em vista que a coisa julgada não é a eficácia da sentença, mas uma qualidade da decisão não mais sujeita a recurso.

Ademais, o artigo 467 da legislação pretérita dizia que a coisa julgada era "a eficácia da sentença", e no artigo 502 do novo Código é "a autoridade da decisão de mérito". Tal mudança constituiu outro avanço no tema, porque não apenas as sentenças transitam em julgado, um acórdão, por exemplo, pode transitar. Além do mais, as decisões interlocutórias que decidem antecipadamente e definitivamente parte do mérito também podem transitar em julgado e serem executadas, sendo decisões eficazes. Trata-se da consagração da coisa julgada parcial. Deste modo, a coisa julgada é a autoridade não mais apenas da sentença, mas da decisão de mérito, seja ela interlocutória, sentença ou acórdão, não mais sujeitos a recurso ordinário ou extraordinário.

Sobre a importância da coisa julgada, Miguel Teixeira de Sousa, no seu livro Estudos sobre o Novo Processo Civil assim preleciona:

O caso julgado é uma exigência da boa administração da justiça, da funcionalidade dos tribunais e da salvaguarda da paz social, pois que evita que uma mesma acção seja instaurada várias vezes, obsta a que sobre a mesma situação recaiam situações contraditórias e garante a resolução definitiva dos litígios que os tribunais são 
Id on Line Revista Multidisciplinar e de Psicologia

Id on Line Revista Multidisciplinar e de Psicologia

chamados a dirimir. (SOUSA, 1997 apud FARIA; THEODORO JUNIOR; NASCIMENTO, 2011, p. 165).

A coisa julgada se mostra imprescindível, pois impede que as partes venham a instaurar uma mesma ação diversas vezes por não concordarem com um resultado que não the foi favorável, isso levaria ao acúmulo de processos e o comprometimento da celeridade processual. Destarte, a coisa julgada impede que uma mesma questão seja analisada e decidida por magistrados diferentes o que poderia ocasionar decisões conflitantes, gerando insegurança jurídica.

\section{Principais Mudanças sobre o instituto da coisa julgada no Novo Código de Processo Civil}

O instituto da coisa julgada foi alvo de grandes transformações com a entrada em vigor do Código de Processo Civil de 2015. A mudança mais substancial diz respeito à coisa julgada de questões prejudiciais incidentais. Inicialmente, cabe ressaltar que as questões que o juiz resolve no processo podem ser incidentais ou principais. As incidentais são examinadas para que se possa decidir sobre a questão principal. As principais constituem o objeto da decisão, o pedido. Assim, para decidir se acolhe ou não o pedido, o Juiz, primeiramente, tem que examinar as questões incidentais, tais como, os fundamentos do pedido, os fundamentos da defesa e questões processuais. A questão principal será resolvida no dispositivo da sentença, enquanto a questão incidental será resolvida na motivação da sentença.

Uma questão prejudicial é prévia e indica como a outra questão será resolvida no processo, podendo incidental ou principal. A tradição em nosso sistema era que a coisa julgada só recaia sobre a solução de questões principais, as incidentais não faziam coisa julgada, por estarem na fundamentação da sentença. O CPC de 2015 rompeu com esta regra, pois além de trazer no caput do art.503 a coisa julgada de questões prejudiciais principais, inovou, disciplinando no $\S 1^{\circ}$ do mesmo dispositivo, a coisa julgada de questões prejudiciais incidentais. Portanto, não apenas o dispositivo da sentença fará coisa julgada, mas também uma parte da motivação.

A despeito de a coisa julgada sempre ter sido entendida como um fenômeno próprio das decisões de mérito, o CPC de 2015 trouxe, ao lado da coisa julgada sobre questões de mérito (artigo 503, caput), a coisa julgada sobre questões processuais. Ocorre nos casos de decisões que extinguem o processo sem resolução de mérito e impedem a repropositura da demanda( $\S 1^{\circ}$ do art. 486 do CPC de 2015). O legislador, inclusive, admite o ajuizamento de rescisória contra essas sentenças (art. 966, §2 do CPC de 2015).

Por fim, o CPC de 1973 considerava como decisão de mérito apenas a que acolhia a prescrição (artigo 269, inciso IV), o novel CPC, contudo, avançando na matéria, considera como de mérito tanto 
Id on Line Revista Multidisciplinar e de Psicoloqia

Id on Line Revista Multidisciplinar e de Psicologia

a decisão que acolhe, como a que rejeita a prescrição (artigo 487, inciso II). Esse entendimento se estende a outras decisões, tais como, a que rejeita a compensação, o direito de retenção, dentre outras. De tal modo, agora a decisão que rejeita direito alegado pelo réu em sua defesa faz coisa julgada.

O objetivo aqui não foi esgotar a matéria, mas fazer uma breve análise das principais alterações pelas quais passou a coisa julgada, com a entrada em vigor do novo Código de Processo Civil, com o fim de possibilitar uma maior compreensão sobre a ampla celeuma doutrinária quanto à possibilidade de sua relativização ou não, fora dos casos previstos em lei.

\section{Instrumentos de controle da coisa julgada}

O direito pátrio admite algumas hipóteses onde, excepcionalmente, a autoridade da coisa julgada pode ser afastada. São exemplos de mecanismos adequados para tal fim: a ação rescisória e a querela nullitatis. Portanto, diante da existência de previsão legal admitindo a desconstituição da coisa julgada de forma típica, tal instituto não pode ser considerado absoluto. Neste sentindo, bem observa o professor Barbosa Moreira (2006, p. 199) que "já que há hipóteses de revisão da coisa julgada típicas, desta forma, já é relativa”.

A ação rescisória é uma ação autônoma que visa à desconstituição de uma decisão de mérito já transitada em julgado, da qual não cabe mais nenhum tipo de recurso, ou seja, que já fez coisa julgada. Pode ser utilizada quando houver vício na decisão que desvie sua finalidade, originando um resultado diferente do esperado pela sociedade e pelo Estado de direito.

A ação rescisória somente é cabível nas hipóteses do artigo 966 do CPC de 2015. Ademais, não pode ser manejada em qualquer tempo, pois possui prazo decadencial de dois anos contados do trânsito em julgado da última decisão proferida no processo, conforme o artigo 975 do mesmo diploma legal. Após o decurso desse prazo, não tendo sido proposta a ação, decai o direito de revisão da sentença pelos fundamentos da ação rescisória.

A novel legislação processual civil inovou em alguns pontos desse instituto. Ilustrando, agora é cabível rescisória de partes da decisão, tendo em vista que o $§ 3^{\circ}$ do artigo 966 do novo CPC assevera que "A ação rescisória pode ter por objeto apenas 1 (um) capítulo da decisão." Além disso, no artigo 975, $\S 2^{\circ}$, o novo Código avançou, a medida que concede prazo diferenciado de cinco anos para propor rescisória quando ocorrer a descoberta de prova nova apta a influenciar no resultado do processo.

A Querela Nullitatis também conhecida como ação declaratória de nulidade de sentença é a ação autônoma de impugnação de decisões que contenham vícios transrecisórios, nos casos de prejuízo ao réu por falta ou defeito na citação. (Artigos 535, inciso I e 525, § 1², inciso I do CPC de 2015). 
Id on Line Revista Multidisciplinar e de Psicoloqia

Id on Line Revista Multidisciplinar e de Psicologia

Alguns doutrinadores defendem que a querela nullitatis é o remédio processual cabível para a desconstituição da coisa julgada de forma atípica, estendendo o seu alcance além dos casos de ausência ou defeito na citação.

A ação rescisória e a Querela Nullitatis se distinguem em dois aspectos: primeiro quanto as hipótese de cabimento e segundo quanto ao prazo para o ajuizamento, a rescisória como vimos está sujeita ao prazo decadencial de dois anos, e a querela não tem prazo, podendo ser proposta a qualquer tempo.

\section{Segurança Jurídica X Justiça}

A polêmica quanto à possibilidade ou não de se relativizar a coisa julgada gira em torno do conflito entre dois princípios que no nosso ordenamento jurídico se encontram no mesmo plano hierárquico (constitucional) e têm a mesma importância: segurança jurídica e o princípio do acesso à ordem jurídica justa. Diante de um caso concreto, qual dos dois deve prevalecer? A solução para este problema está, a nosso ver, em basear a decisão no princípio da proporcionalidade.

De um lado, os que defendem não ser possível a relativização da coisa julgada baseiam-se no princípio da segurança jurídica, também conhecido como princípio da estabilidade das relações jurídicas, que significa a certeza de que essas relações estão cristalizadas no tempo. Desde antigamente as sociedades já lutavam por esse ideal que hoje se encontra nos nossos sistemas jurídicos estando intimamente ligado ao Estado Democrático de Direito dando-lhe sustentação.

Neste sentido Fabricio dos Reis Brandão afirma:

O Direito Brasileiro considera o princípio da segurança jurídica como basilar para nosso ordenamento jurídico, uma vez que este instaura a "paz" e a estabilidade no mundo jurídico, que é um pressuposto básico que gera um clima de confiança em seu conteúdo. (BRANDÃO, 2005, p. 23).

Deste modo tal princípio mostra-se imprescindível para qualquer Estado Democrático de Direito, pois impede a perpetuação de incertezas que, se existissem, transformariam o mundo jurídico em uma grande desordem, pois na sociedade não haveria paz, nem tranquilidade quanto à certeza do seu direito.

O referido princípio não se encontra expresso na nossa Constituição Federal, estando de forma implícita, podendo ser extraído de algumas passagens constitucionais como, por exemplo, no artigo $5^{\circ}$, inciso XXXVI, in verbis: "a lei não prejudicará o direito adquirido, o ato jurídico perfeito e a coisa julgada". 
Id on Line Revista Multidisciplinar e de Psicologia

Id on Line Revista Multidisciplinar e de Psicologia

A segurança jurídica não existe por si só, necessitando de instrumentos para se efetivar, dentre eles podemos citar o direito adquirido, a coisa julgada, o ato jurídico perfeito. A coisa julgada é um dos principais instrumentos que efetivam esse princípio, imprimindo-lhe força.

Do outro lado da discussão, os que defendem a relativização da coisa julgada baseiam-se no princípio do acesso à ordem jurídica justa, também conhecido como princípio da inafastabilidade da jurisdição ou da ubiquidade da justiça.

Este princípio, assim como o da segurança jurídica é implícito ao Estado Democrático de Direito. A Constituição Federal em seu artigo $5^{\circ}$, inciso XXXV traz a inafastabilidade da prestação jurisdicional ao dispor que "a lei não excluirá da apreciação do Poder Judiciário lesão ou ameaça a direito".

$\mathrm{Na}$ primeira leitura deste artigo tenderíamos a pensar que este princípio trata apenas da inafastabilidade da jurisdição. Ocorre que devemos fazer uma análise desse dispositivo de forma ampla, pois isso nos permitirá abarcar o entendimento de que não apenas o acesso ao judiciário deve ser alcançado, mas também que uma prestação de tutela jurisdicional adequada e efetiva é aquela que é justa.

Desta forma, Watanabe (1998, p. 128) assevera:

A problemática do acesso à Justiça não pode ser estudada nos acanhados limites do acesso aos órgãos judiciais já existentes. Não se trata apenas de possibilitar o acesso à Justiça enquanto instituição estatal, e sim de viabilizar o acesso à ordem jurídica justa.

Assim, quando um cidadão tem um conflito de interesses e busca resolvê-lo através da provocação do Judiciário, tem direito não somente à prestação da tutela jurisdicional, mas também que seu litígio seja solucionado com justiça.

O princípio da proporcionalidade deve ser levado em consideração sempre que outros princípios constitucionais implícitos ou explícitos estejam em conflito. Nesta altura, cumpre informar que o conflito de normas ou princípios da Constituição é apenas aparente em virtude da harmonia das normas constitucionais. Isto é, a Constituição deve ser interpretada de tal forma que suas normas estejam sempre em harmonia. Em análise ao caso concreto, não detidamente é possível vislumbrar conflitos aparentes, contudo o princípio da proporcionalidade tem a função de solucioná-los determinando o que se deve aplicar ao caso concreto.

Sobre ele afirma Fabricio dos Reis Brandão (2005, p. 55):

Vale dizer que esse princípio não está expresso de forma individualizada na Constituição Federal, porém, a fórmula política adotada pelo nosso legislador constituinte, qual seja a do Estado Democrático de Direito, torna inafastável a ideia de sua aplicação.

É mais um princípio importante na nossa ordem constitucional vigente utilizado para solucionar o conflito entre outros princípios importantes no nosso ordenamento jurídico, cujo 
Id on Line Revista Multidisciplinar e de Psicoloqia

Id on Line Revista Multidisciplinar e de Psicologia

sacrifício total a nenhum deles seja razoável exigir. Tenta harmonizar os princípios conflitantes de maneira que a lide se resolva da forma mais ponderada possível, evitando que atitudes desproporcionais sejam cometidas.

O juiz deve buscar, sempre que possível, em casos conflituosos, nunca aplicar de forma pura um único princípio, pois outro seria ferido. Por isso deve-se relativizar, flexibilizar, ou seja, deve-se tentar utilizar um pouco de cada um de tal forma que o conflito se reduza o máximo possível.

Assim, para a resolução de conflito sobre a prevalência da segurança jurídica ou do acesso à ordem jurídica justa, cabe a aplicação do princípio da proporcionalidade. Exercendo o juízo de ponderação, o aplicador do direito verificará qual dos dois tem maior peso para solucionar a situação. Nestes casos, um dos princípios será utilizado em maior abrangência, porém o outro não deve ser totalmente desprezado, visto que ambos são essenciais para a regular a existência do nosso sistema jurídico. Desta forma, objetiva-se impedir que na solução da situação sejam lesados direitos e garantias fundamentais, ou, se não for possível, que isto ocorra da forma menos prejudicial possível.

\section{Posições doutrinárias favoráveis à relativização da coisa julgada}

O nosso ordenamento jurídico previu determinados instrumentos de relativização da coisa julgada, sendo eles a ação rescisória e a querela nullitatis, que são os chamados meios típicos de relativização.

O que a doutrina diverge é quanto à possibilidade de relativizar a coisa julgada fora das hipóteses já previstas pelo ordenamento pátrio, movimento que vem propondo a chamada relativização atípica da coisa julgada. Eles dizem que se a decisão for injusta ou inconstitucional a desconstituição pode ocorrer por qualquer meio, a qualquer tempo, independentemente do grau de jurisdição em que se encontre a decisão.

Para esses doutrinadores a relativização deveria ocorrer com fundamento no princípio do acesso à ordem jurídica justa, pois a segurança jurídica não seria um valor absoluto, não podendo prevalecer diante de uma sentença injusta ou que viole princípios básicos do ordenamento jurídico vigente, ou quando no processo tiver ocorrido fraude, ou violação a direitos e garantias fundamentais ou ainda quando posteriormente a lei na qual a sentença foi fundamentada for declarada inconstitucional.

Os que são a favor desse pensamento não estão afirmando que a segurança jurídica seja um princípio de menos importância, nem pretendem acabar com o instituto da coisa julgada, mas sim, contextualizá-lo no ordenamento jurídico e dar-lhe, de forma eficaz e eficiente, a função que lhe é própria, sem prejudicar outros institutos de maior ou de mesma relevância que ele. (BRANDÃO, 2005, p. 104). Para eles a coisa julgada é instituto constitucional relativo, como todos os outros 
Id on Line Revista Multidisciplinar e de Psicoloqia

Id on Line Revista Multidisciplinar e de Psicologia

previstos na Constituição, não existindo mais em nosso ordenamento princípios ou institutos absolutos.

O primeiro a tratar dessa questão no Brasil foi o magistrado e ex-ministro do Superior Tribunal de Justiça, José Augusto Delgado. Tendo muita experiência na análise de casos concretos defendeu que a coisa julgada deve ser relativizada sempre que afronte princípios como o da moralidade, legalidade, razoabilidade e proporcionalidade, ou quando se desafine com a realidade dos fatos. (2001, apud DIDIER JR, 2009, p. 441).

Desta forma, para este jurista a coisa julgada não é absoluta, podendo ser desconstituída em caso de desrespeito a princípios constitucionais, pois considera que estes estão acima deste instituto. Também diante de uma decisão totalmente contrária a realidade fática não faz sentido manter a coisa julgada intocável, pois a prestação jurisdicional deve servir como instrumento de pacificação social e não como causadora de injustiças sociais.

Afirma, ainda, que sendo o Judiciário um dos poderes do Estado tem a obrigação de fazer cumprir a moralidade, a legalidade, o respeito à Constituição e, especialmente, a garantia da entrega da justiça. Não se pode conceber coisa julgada que faz o contrário intocável. (DELGADO 2002, p. 100)

Segundo o doutrinador Cândido Rangel Dinamarco, o princípio da segurança jurídica e o instituto da coisa julgada não podem ser considerados absolutos, pois tem diante de si o princípio do acesso à ordem jurídica justa, não apenas a garantia de acesso aos órgãos do Poder Judiciário, mas também a certeza de que haverá justiça na decisão, conforme artigo $5^{\circ}$, inciso XXXV da nossa Constituição Federal. (DINAMARCO, 2002, p.39).

Sendo ambos os princípios, segurança jurídica e acesso à ordem jurídica justa, considerados fundamentais para o sistema constitucional, um não pode ser tido por absoluto em detrimento do outro. Não podendo, por conseguinte a coisa julgada permanecer intocável com base na supremacia do princípio da segurança jurídica, devendo ser desconstituída todas as vezes que atacar valores constitucionais ou for extremamente injusta.

Para Tereza Arruda Alvim Wambier e José Miguel Garcia existem vícios que maculam as sentenças de tal modo que elas se tornam inexistentes, não transitando em julgado, e não formando a coisa julgada. Sendo que o remédio processual cabível, na concepção desses autores, é a ação declaratória de inexistência (Querela Nullitatis). As decisões que tiverem sentenças inexistentes não precluem, podendo a qualquer momento vir a serem declaradas inexistentes. (WAMBIER; MEDINA, 2003, p. 26).

Carlos Valder do Nascimento, Humberto Theodoro Júnior e Juliana Cordeiro de Faria são autores da obra "Coisa Julgada Inconstitucional: A questão da Segurança Jurídica", onde defendem a relativização da coisa julgada:

Qualquer que seja o sistema processual contemporâneo e por maior e por maior que seja o prestígio que se pretende conferir à coisa julgada, impossível será recusar a 
possibilidade de superveniência de sentenças substancialmente nulas, mesmo depois de esgotas a viabilidade recursal ordinária e extraordinária. À parte prejudicada pela nulidade absoluta, ipso iure, não poderá a Justiça negar o acesso à respectiva declaração de invalidade do julgado. (FARIA; THEODORO JUNIOR; NASCIMENTO, 2011, p. 252).

A sentença baseada em vício grave contém nulidade ipso iure (absoluta) devendo a coisa julgada ser invalidada, não podendo subsistir nesses casos. Essas nulidades não podem se convalidar com tempo, porque delas decorrem prejuízos graves às partes. Para eles sempre existirão casos de sentenças nulas, não podendo a justiça negar a declaração de invalidade simplesmente porque se esgotaram as possibilidades de recursos. Defendem que o meio adequado para atacar tais decisões nulas é a Querela Nullitatis.

Fabrício dos Reis Brandão (2005, p. 101) entende que: "Não parece ser coerente o surgimento de decisões injustas, maculadoras do próprio Estado Democrático de Direito, e estas serem agasalhadas pelo manto da coisa julgada material".

A Constituição empresta validade a todas as normas hierarquicamente inferiores, sendo que todos os atos estatais são a ela vinculados, sob pena de nulidade. No entanto, os princípios que emanam da própria Constituição podem entrar em conflito entre si. A solução para esse problema é utilizar o princípio da razoabilidade e proporcionalidade. Assim, de acordo com o caso concreto em análise, deve-se utilizar o princípio da proporcionalidade para saber se prevalecerá a justiça ou a segurança jurídica. Admite-se, então, em determinados casos, a relativização da coisa julgada com base no princípio da proporcionalidade, pois decisões injustas não podem ser protegidas pelo manto da coisa julgada, isso afrontaria os princípios mais elementares do Estado Democrático de Direito. (BRANDÃO, 2005, p. 101).

O Supremo Tribunal Federal e o Superior Tribunal de justiça já se manifestaram pela aceitação da tese da relativização da coisa julgada, em alguns casos, a exemplo das decisões já transitadas em julgado de investigação de paternidade, quando posteriormente se descobre que não corresponde a realidade fática. Neste sentido:

[...] Deve ser relativizada a coisa julgada estabelecida em ações de investigação de paternidade em que não foi possível determinar-se a efetiva existência de vínculo genético a unir as partes, em decorrência da não realização do exame de DNA, meio de prova que pode fornecer segurança quase absoluta quanto à existência de tal vínculo. [...] (STF. RE 363889 DF. Rel. Min. Dias Toffoli. 02/06/2011).

[...] Na primitiva ação de investigação de paternidade proposta, a improcedência do pedido decorreu de confissão ficta pelo não comparecimento da mãe do investigando à audiência de instrução designada. Considerando, assim, que a paternidade do investigado não foi expressamente excluída por real decisão de mérito, precedida por produção de provas, impossível se mostra cristalizar como coisa julgada material a inexistência do estado de filiação, ficando franqueado ao autor, por conseguinte, o ajuizamento de nova ação. É a flexibilização da coisa julgada. [...] (STJ. REsp 427.117 / MS. $3^{\mathrm{a}}$ T. Relator Ministro Castro Filho. Data da Publicação 16.02.2004.). 
Id on Line Revista Multidisciplinar e de Psicologia

Id on Line Revista Multidisciplinar e de Psicologia

Assim, na concepção estes renomados juristas, o acesso à ordem jurídica justa é princípio primeiro, em detrimento da segurança jurídica que deve vir em segundo plano, pois não se pode conceber que em nome da mesma se admitam decisões injustas, totalmente diferentes da realidade ou até mesmo inconstitucionais.

\section{Posições doutrinárias contrárias à relativização da coisa julgada}

Em que pese à doutrina favorável à relativização da coisa julgada, temos outros grandes estudiosos do direito contra essa posição, entre eles podemos destacar: Fredie Didier Jr., Elpídio Donizetti, Luiz Guilherme Marinoni e Nelson Nery Júnior.

Dentre seus principais argumentos está a segurança jurídica, considerado valor primeiro implicitamente previsto na Constituição Federal de 1988, calcado como cláusula pétrea, embasando o Estado Democrático de Direito, estando acima inclusive do valor Justiça.

Consideram que a coisa julgada não deve ser desconstituída fora das hipóteses já admitidas pela lei, pela doutrina e pelos tribunais, tendo por fundamento injustiças, pois o conceito de justiça é abstrato, e sobre ele pode haver discordância. Se possível à desconstituição da coisa julgava sempre que alguém se sentir injustiçado, os litígios nunca serão resolvidos, porque quase sempre uma parte ficará insatisfeita com o resultado da demanda. A consequência será a eternização de processos.

Acreditam também que a desconstituição da decisão já amparada pela coisa julgada com base em inconstitucionalidade gera sérios problemas, pois, a qualquer tempo se a lei for declarada inconstitucional, a decisão poderá mudar, e as relações já constituídas por ela que estavam seguindo um rumo certo serão modificadas. Isso fere a segurança jurídica, pois onde ficará à garantia das partes quanto à certeza da estabilidade da decisão e do seu direito?

Esses doutrinadores admitem que pode acontecer de a coisa julgada vir a perenizar injustiças, decisões desarrazoadas da realidade ou até mesmo inconstitucionais, nestes casos deve-se utilizar os institutos já previstos em lei, ou admitidos pela doutrina e tribunais para desconstituí-la. Em não sendo possível a utilização desses meios, esses estudiosos acham que não se deve relativizar, pois a segurança jurídica, como já dito, é valor mais importante.

O professor e advogado Fredie Didier Júnior teme que, permitindo ao Judiciário a relativização da coisa julgada com base em injustiças, acabe surgindo uma espécie de cláusula geral de revisão da coisa julgada, que permitirá a sua desconstituição em quase todas as situações, visto que surgirão várias formas de interpretações, cada um querendo ter direito à modificação da decisão para se beneficiar, banalizando-se assim o instituto da coisa julgada e ferindo o princípio constitucional da segurança jurídica. (DIDIER, JR. 2009, p. 442). 
Id on Line Revista Multidisciplinar e de Psicoloqia

Id on Line Revista Multidisciplinar e de Psicologia

Ademais, Didier Jr. não é muito simpático à ideia da relativização com base na inconstitucionalidade, pois:

Também a relativização com base na inconstitucionalidade é problemática, pois a qualquer momento que a lei em que se fundou a decisão fosse reputada inconstitucional, a decisão poderia ser desconstituída. Com isso, malferir-se-ia frontalmente a garantia da segurança jurídica. (DIDIER JR, 2009, p. 443).

O desembargador Elpídio Donizetti também não concorda com a ideia da relativização da coisa julgada e rebate o argumento de parte da doutrina favorável à relativização que afirma que a coisa julgada não recebeu tratamento constitucional em sim, mas apenas infraconstitucional, pois o constituinte estava apenas querendo colocá-la a salvo dos efeitos da lei nova. Para ele, ao contrário, a coisa julgada é cláusula pétrea, não podendo ser modificada nem pelo legislador, nem por juízes, nem por outros agentes estatais. Também não admite a desconstituição com base em injustiças, porque, se fosse possível, seria necessário a repropositura da ação e os conflitos nunca chegariam ao fim. (DONIZETTI, 2009, p. 418).

Para o jurista Luiz Guilherme Marinoni de nada adianta falar em direito de acesso à justiça sem dar ao cidadão o direito de ver o seu conflito solucionado definitivamente. A coisa julgada pode, em alguns casos, produzir situações indesejáveis ao próprio sistema, mas, em razão disso, não se deve imaginar que ela deve ser desconsiderada. Diante de comportamentos inadequados, o Estado-Juiz previu na lei hipóteses onde poderá a coisa julgada ser desconsiderada, objetivando assim não eliminar a garantia de solução definitiva dos conflitos, que é necessária à efetividade do direito de acesso aos tribunais e à segurança e à estabilidade da vida dos cidadãos. (MARINONI, 2005, p. 1).

Nelson Nery Júnior assim afirma (2004, p. 501):

\begin{abstract}
A segurança jurídica, trazida pela coisa julgada material, é manifestação do Estado Democrático de Direito. Entre o justo absoluto, utópico, e o justo possível, realizável, o sistema constitucional brasileiro optou pelo segundo(justo possível), que é consubstanciado na segurança jurídica da coisa julgada material. Descumprirse a coisa julgada material é negar o próprio Estado Democrático de Direito, fundamento da República brasileira.
\end{abstract}

Para este jurista a coisa julgada é elemento de existência do Estado Democrático de Direito, pois se fundamenta na segurança jurídica. Deste modo, não se pode conceder a este instituto tratamento jurídico inferior, de direito processual civil (lei ordinária), como querem alguns juristas. Tendo em vista a importância da coisa julgada, não poderá ser relativizada sob o argumento de sentença injusta ou inconstitucional.

Ele acredita que os atos jurisdicionais devem sim estar sujeitos ao controle de constitucionalidade, mas que este deve ser feito sob o devido processo legal, por meio dos instrumentos previstos no ordenamento jurídico brasileiro, tais como recurso extraordinário, recurso 
Id on Line Revista Multidisciplinar e de Psicoloqia

Id on Line Revista Multidisciplinar e de Psicologia

ordinário, ação rescisória, embargos do devedor, coisa julgada segundo o resultado da lide e revisão criminal. (NERY, 2004, p. 508-512).

Assim, na visão destes juristas, o princípio da segurança jurídica tem posição privilegiada no sistema e fundamenta a própria concepção de Estado como sociedade politicamente organizada. Deve, portanto, prevalecer sobre o princípio do acesso à ordem jurídica justa. A coisa julgada é entendida como instituto constitucional, protegida sob o manto das cláusulas pétreas, não podendo ser desconstituída por outros meios além dos já previstos no ordenamento jurídico pátrio. Permitir que em qualquer hipótese seja desconstituída com base em injustiças ou inconstitucionalidades geraria grave insegurança jurídica.

\section{Conclusão}

A doutrina brasileira vem se digladiando há alguns anos acerca da possibilidade da relativização da coisa julgada fora das hipóteses previstas em lei para tal fim. Os que defendem a relativização se baseiam no princípio do acesso à ordem jurídica justa, e afirmam que sentenças maculadas pela injustiça ou inconstitucionais devem ser desconstituídas, pois o fim de uma decisão judicial é a pacificação social e não a perenização de injustiças.

De outro lado, os doutrinadores que não aceitam a relativização embasam sua posição no princípio da segurança jurídica. Todo aquele que leva uma lide a justiça quer vê-la solucionada definitivamente, quer certeza quanto ao seu direito ou não. A desconstituição do julgado por qualquer meio e em qualquer grau de jurisdição só faria com que o Poder Judiciário entrasse em descrédito perante a população.

Com o objetivo de oferecer um maior embasamento ao tema proposto analisamos os aspectos gerais sobre o instituto da coisa julgada, a saber, o conceito dado pela nova legislação processual civil de 2015, a importância e a distinção entre coisa julgada formal e material.

Discorremos, também, acerca das medidas típicas para relativização da coisa julgada, que são a ação rescisória capaz de desconstituir uma sentença transitada em julgado nas hipóteses previstas em lei (artigo 966 do CPC de 2015) e a Querela Nullitatis Insanabilis utilizada nos casos dos artigos (Artigos 535, inciso I e 525, $\S 1^{\circ}$, inciso I do CPC de 2015).

Analisamos, ainda, algumas transformações pontuais pelas quais passou a coisa julgada com o advento do novo Código de Processo Civil. Ademias, avaliamos os principais argumentos doutrinários contrários e favoráveis à tese da relativização da coisa julgada de forma atípica. E, por fim, sopesamos os princípios constitucionais que estão em conflito. 
Id on Line Revista Multidisciplinar e de Psicoloqia

Id on Line Revista Multidisciplinar e de Psicologia

O cerne do tema proposto é saber qual dos dois princípios constitucionais deve prevalecer no caso concreto, se a segurança jurídica ou o acesso à ordem jurídica justa. Acontece que ambos estão no mesmo nível hierárquico constitucional, ou seja, tem a mesma importância.

A solução para a problemática a nosso ver é submeter à questão ao princípio da proporcionalidade, através da ponderação pode o julgador, em um determinado caso, analisando todas as situações fáticas e jurídicas envolvidas, decidir pela utilização mais abrangente de um dos princípios em detrimento do outro, sem, contudo, desprezá-lo totalmente, pois ambos são essenciais à existência do Estado Constitucional Democrático.

Assim, temos que, por meio do princípio da proporcionalidade (ponderação), a coisa julgada pode ser relativizada fora das hipóteses previstas em lei em casos onde se verifique uma grave injustiça ou inconstitucionalidade, pois aceitar por mero formalismo uma decisão desarrazoada da realidade seria regredir a um Estado unicamente de direito, vinculado apenas à letra fria da lei, sem dar importância a princípios consagrados que visam evitar injustiças.

Com este pensamento não se pretende colocar a segurança jurídica em segundo plano, pois é valor básico para o nosso sistema jurídico, apenas não se pode comungar da ideia de coisa julgada absoluta a qualquer custo, sem respeito à verdade do caso concreto.

Além do que, não se deve desconstituir a coisa julgada por qualquer meio, de todo jeito. $\mathrm{O}$ princípio da proporcionalidade (ponderação) só deve considerar o acesso à ordem jurídica justa de maior abrangência se no caso concreto verificar-se que houve uma séria injustiça ou inconstitucionalidade.

Assim, tem-se que é constitucional a relativização da coisa julgada em situações excepcionais, onde se verifique grave inconstitucionalidade ou injustiça, tendo em vista que o nosso Estado Constitucional de Direito veda princípios ou valores absolutos e visa à pacificação social.

\section{Referências}

BRANDÃO, Fabricio dos Reis. Coisa Julgada. São Paulo: MP Editora Ltda., 2005.

BRASIL. Lei $\mathbf{n}^{\circ} 5869$ de 11 de janeiro de 1973. Código de Processo Civil. Disponível em: http://www.planalto.gov.br/ccivil 03/leis/L5869.htm. Acesso em: 23/02/2016.

BRASIL. Lei $\mathbf{n}^{\mathbf{0}}$ 13.105, de 16 de março de 2015. Institui o Código de Processo Civil. Disponível em: http://www.planalto.gov.br/ccivil 03/ ato2015-2018/2015/lei/113105.htm. Acesso: 22/02/2016.

BRASIL. Constituição da República Federativa do Brasil de 05 de outubro

de1988. Disponívelem: $<$ http://www.planalto.gov.br/ccivil 03/constituicao/ConstituicaoCompilado.ht m> Acesso em:20/02/2016. 
Id on Line Revista Multidisciplinar e de Psicoloqia

Id on Line Revista Multidisciplinar e de Psicologia

BRASIL. Supremo Tribunal Federal. RE: 363889 DF. Relator: Ministro Dias Toffoli. Data de Julgamento: 02/06/2011. Tribunal Pleno. Data de Publicação: 16-12-2011. Disponível em: <http://www.stf.jus.br>

BRASIL. Superior Tribunal de Justiça. Recurso Especial $\mathbf{n}^{\mathbf{0}}$ 427.117/RS. Relator Ministro Castro Filho. Data de Julgamento: 04/11/2003. 3. Turma. Data da Publicação: 16/02/2004. Disponível em: $<$ http://www.stj.jus.br>

DELGADO, José Augusto. Efeitos da coisa julgada e princípios constitucionais. In: NASCIMENTO, Carlos Valder do (Coord.). Coisa julgada Inconstitucional. Rio de Janeiro: América Jurídica, 2002.

DIDIER JR, Fredie. Curso de Direito Processual Civil. Vol. 2. Salvador: Podivm, 2009.

DINAMARCO, Cândido Rangel. Relativizar a coisa julgada material. In: NASCIMENTO, Carlos Valder do (Coord.). Coisa Julgada Inconstitucional. Rio de Janeiro: América Jurídica, 2002.

DONIZETTI, Elpídio. Curso Didático de Direito Processual Civil. 11. ed. Rio de Janeiro: Lumen Juris, 2009.

MARINONI, Luiz Guilherme; ARENHART, Sérgio Cruz. Manual do processo de conhecimento, 4. ed., rev., atual. E ampl. São Paulo: Revista dos Tribunais, 2005.

NASCIMENTO, Carlos Valder do; THEODORO JÚNIOR, Humberto; FARIA, Juliana Cordeiro de. Coisa julgada inconstitucional: a questão da segura jurídica. Belo Horizonte: Fórum Ltda, 2011.

NERY JÚNIOR, Nelson. Teoria Geral dos Recursos. 6. ed. São Paulo: Revista dos tribunais, 2004.

WAMBIER, Tereza Arruda Alvim; MEDINA, José Miguel Garcia. O Dogma da Coisa Julgada: hipóteses de relativização. São Paulo: Revista dos Tribunais, 2003.

WATANABE, Kazuo. Acesso à Justiça e sociedade Moderna, in Participação e processo. São Paulo: Revista dos Tribunais, 1988.

Como citar este artigo (Formato ABNT):

GINO, B.S.B.D.; SILVA, E.S.F.; DANTAS, T.C.C.P. A Relativização da coisa julgada: Um conflito entre a Segurança Jurídica e a justiça da decisão. Id on Line Revista Multidisciplinar e de Psicologia, Julho de 2016, vol.10, n.30, p. 302-317. ISSN 1981-1179.

Recebido: $15 / 06 / 2016$

Aceito: 30/06/2016 